\title{
Accessory phase petrochronology under pressure: Unravelling the history of Grenvillian eclogites
}

Charles Kavanagh-LePage ${ }^{1}$, FÉlix Gervais ${ }^{1}$, TOMAS NÆRAA ${ }^{2}$, ABDELALI MOUKHSIL ${ }^{3}$

${ }^{1}$ Polytechnique Montréal, Québec, Canada, H3T 1J4

(*correspondence : charles.kavanagh-lepage@polymtl.ca) ${ }^{2}$ Lund University, 22100 Lund, Sweden

${ }^{3}$ MERNQ, Québec, Canada

The Grenvillian Orogeny is interpreted as a long-hot orogen (LHO) marked by protracted metamorphic and deformation episodes. Our study area, in the central Grenville Province, Québec, Canada, encompasses the lowermost unit of the hinterland, the eclogite-bearing Manicouagan Imbricate Zone (MIZ) and is an ideal location to study high-pressure mineral assemblages present in meta-mafic rocks. In this study, we combine Scanning Electron Microscopy (SEM), simultaneous in situ U-Pb and trace element LA-ICP-MS with phase equilibria modeling, to rebuild the PressureTemperature-time (P-T-t) path of a retrogressed eclogite sample and highlight intricate relationships between titanite, rutile and allanite.

In our sample, both titanite and allanite occur in the matrix. Rutile is found as inclusions in garnet or overgrown by titanite. SEM analysis reveal complex zonation patterns in allanite grains reflecting changing LREE concentrations. Phase equilibria modeling predicts that, along a prograde path, zoesite and titanite coexist and breakdown together in favor of rutile and excess water. With zoesite and titanite breaking down, a problem arises for the budget of LREE. As suggested by Hermann [1], allanite may form at the expense of zoesite and is stabilized by available LREE. Thus, the growth zonation observed in allanite grains could be explained by the liberation of LREE during zoesite and titanite breakdown. Zr-in-rutile and Zr-in-titanite thermobarometry, coupled to phase equilibria modeling, indicate titanite growth after rutile during decompression at $\mathrm{P}-\mathrm{T}$ conditions higher than $1.5 \mathrm{GPa}$ and $850^{\circ} \mathrm{C}$. Also, Eu anomalies and REE profiles support high-grade titanite genesis. In a Tera-Wasserburg diagram, the uncorrected titanite data yields a radiogenic-common $\mathrm{Pb}$ mixing line with a lower intercept of $1034 \mathrm{Ma} \pm 10$.

Thus, our investigation of petrogenetic relations amongst high-P minerals unravels a complex metamorphic history for eclogites in the MIZ, culminating in titanite genesis during decompression and, consequently, marking the onset of exhumation.

[1] Hermann (2002) Chem. Geology 192 289-306 